\title{
Do Students Get Enough Information Systems Education in the Business Core?
}

\author{
Janos T. Fustos ${ }^{1}$, Gerard J. Morris ${ }^{1}$, Wayne A. Haga ${ }^{1}$ \\ ${ }^{1}$ Department of Computer Information Systems and Business Analytics, Metropolitan State University of Denver, \\ Denver, CO 80204, USA \\ Correspondence: Janos T. Fustos, Department of Computer Information Systems and Business Analytics, Metropolitan \\ State University of Denver, Denver, CO 80204, USA.
}

Received: March 27, 2017

doi:10.11114/bms.v3i2.2303

\author{
Accepted: April 20, $2017 \quad$ Online Published: May 14, 2017
}

URL: https://doi.org/10.11114/bms.v3i2.2303

\begin{abstract}
Information Systems/Technology is a key component in today's business infrastructures with a myriad of ever-increasing and innovative applications fuelling the drive for competitive advantage. Therefore information systems education should be a critical element in business schools programs today to appropriately prepare students to be competitive. As our university was seeking AACSB accreditation we wanted to investigate what other programs were doing for the information systems area in the business core. Therefore data was acquired from 61 peer institutions, $89 \%$ of which are AACSB-accredited. Data about the components of the business core were collected from the university websites and analysed to determine the amount of the business core curriculum devoted to information systems. Analysis indicates that $85 \%$ of the peer institutions had one information systems course and only three percent had two information systems courses.
\end{abstract}

Keywords: technology, information systems, education, business core, curriculum

\section{The Role of Technology}

\subsection{Role of Technology in General}

Information technology plays an increasingly widespread and important role in our lives. More and more researchers report that new technical solutions not only change old behavioural patterns, but also create many new ones (Massimi, Dimond \& Le Dantec, 2012; Barry, 2012; MacKay \& Vogt, 2012; Gruzd \& Haythornthwaite, 2011). There are three major developments that provide strong indications of these changes: extensive technology solutions and Internet services are available in households; increased access to networks from everywhere and on any device; and since more tasks can be completed online we spend more time on the networks. (Haythornthwaite, 2001; Raghavan, 2006) Furthermore, the Internet is not just a technical solution, a network linking computers and servers, but also a grid linking people. Internet communication services offer the possibility to establish multilateral relationships that are independent of spatial co-presence (Hargittai, 2007).

\subsection{Role of Technology in Business}

Authors report worldwide about the current state of the information and communication technology (ICT) adoption in private and public organizations. Reports investigate ICT infrastructure, mobile communications, data access, enterprise resource planning systems, wireless data services, productivity and business application software used, drivers for ICT investment, perceptions about business benefits of ICT, outsourcing trends and availability of help and advice on ICT adoption. Studies also have investigated major barriers in ICT adoption with the findings that there is an increased need for more training (Manochehri, Al-Esmail, \& Ashrafi, 2012; Raphaeli, Naveh, Levi, Berman, \& Fink, 2012; Evangelista \& Vezzani, 2012).

Additional research indicated that lack of various computer skills and difficulty accepting the use of new technology are creating personal issues. The workplace technology requirements often also create anxiety. The study suggests that computer users have to keep up with and adapt to new technology and its applications since computer anxiety is a natural consequence of performing heavy, routine job tasks (Shah, Hassan, \& Embi, 2012).

\subsection{Role of Technology in Education}

Rapid development of IT technology has created several challenges for IT education: rapid, ever-increasing flood of new 
information; half of what students learn about IT in their first year of study is already obsolete after three years; estimates show that we are only in the middle of the information revolution; very heterogeneous population of students having very different background knowledge, students who record lectures (when and if they are present) with their mobile devices and phones, and communicate with their mentors sending links to video clips in YouTube; and the changing nature of colleges and universities. The reality is that students of the 21 st century need a technology-based education to survive in a technological world. This is echoed in the first draft of the National Educational Technology Plan (NETP), released in April 2010 by the U.S. Department of Education. "Just as technology is at the core of virtually every aspect of our daily lives and work, we must leverage it to provide engaging and powerful learning experiences" (Daggett, 2010).

In 2011 Babson Survey Research Group and the College Board reported that 6.1 million students took at least one online course during the fall 2010 term. The $10 \%$ growth rate for online enrolments far exceeds the $2 \%$ growth in the overall higher education student population (Allen \& Seaman, 2011). That means that to participate in those virtual classrooms students need a default set of technical skills to succeed. (Hamilton, 2010) Some of the most important ones include the appropriate use of Internet searches, Microsoft Office Suite and other end-user applications, keyboarding, safety and security, hardware basics and troubleshooting, backing up data, and finding applications and software.

In an interview in June 2012 Bill Gates talked about the impact of technology on education. He thought that the recent technology changes that influenced teaching/learning process were more fundamental than any previous developments and we still have to figure it out "... where is technology the best and where is the face-to-face the best" (Young, 2012). But the whole value of higher IT education is sometimes questioned (Henno, Jaakkola, \& Makela, 2012).

Accreditation requirements for business programs highlight the importance of information acquisition, management, and reporting topics in the curriculum. Both previous and current Association to Advance Collegiate Schools of Business (AACSB) standards include such areas in degree programs with a very strong emphasize stating that "The school must determine the specific ways globalization and information systems are included in the curriculum, and the particular pedagogies used. Curricula without these two areas of learning would not normally be considered current and relevant." (AACSB, 2003) The latest revision details requirements for both skills ("Information technology - able to use current technologies in business and management contexts") and general knowledge areas ("Information technology ... data creation, data sharing, data analytics, data mining, data reporting, and storage between and across organizations including related ethical issues") (AACSB, 2013).

\section{What Do Students Know?}

Previous studies showed that the assumption that incoming business students possess adequate knowledge of computer concepts and also computer literacy skills is not accurate. Some students may eventually pick up some technology skills and computer concepts during their studies but that may not be to the degree that potential employers require (Wallace \& Clariana, 2005).

Many university professors assume that students bring some technology knowledge and skills with them when they enter higher education. But even educational professionals argue that may not be enough and "... colleges and universities must work to ensure that their students graduate prepared for a workforce in which they will constantly be asked to use technology" (Groux, 2012). Researchers also argue that computer skills are becoming part of general college knowledge and should be emphasized - especially in business education (Shaofu, 2012).

Studies show that there are differences in student perceptions of their computer skills and their actual knowledge. (Grant, Malloy, \& Murphy, 2009) The ability of the students to maintain a computer and to develop a website improves at the university level but not the ability to use the Internet or to apply basic information and communication technology skills. Students' perceptions on different information systems topics - hardware, software, technology management, applications etc. - make it challenging to develop and deliver business information systems courses (Rob \& Etnyre, 2015). Researchers also found that having a certain learning style might influence the perception of students of their ICT skill (Verhoeven, Heerwegh, \& De Wit, 2012). Higher education institutions need to learn more about students' digital readiness to be more successful with course and curriculum design including prerequisite arrangements. (Thorell, Fridorf-Jens, Lassen, Lange, \& Kayser, 2015) Literature describes efforts that try to develop standardized tests and evaluation methods to assess information literacy levels in higher education measuring both before and after taking relevant courses (Boh Podgornik, Dolničar, Šorgo, \& Bartol, 2015).

\section{What Do Students Need To Know?}

A research report by the Institute for the Future (an independent, non-profit strategic research group) shows that preparing for a specific career area based on content is difficult and, instead, students should develop certain broad skills. The report provides thoughts and explanations for each of the skills in detail, and also goes into the implications for education and policies. They identified six drivers for changes (extreme longevity, rise of smart machines and 
systems, computational world, new media ecology, super-structured organizations, and a globally connected world) and mapped ten skills around them, which they believe will be critical for success in the workforce. Several of them are directly related to technology (computational thinking, new media literacy, virtual mind-set, and virtual collaboration.) They emphasize the need and importance of such education (Davies, Fidler \& Gorbis, 2011).

Schools in the US and EU (France, Denmark, UK) are working closely with businesses to assure that students are well prepared for the challenges in the digital era. "If you are trying to prepare business students for the world and you are not taking into account digital technology, you are failing in your mission." (Schuetze, 2012) A case study from India showed that integrating technology into curriculum and also using it as an environment for online or hybrid management courses are beneficial for students, institutions, and future employers (Mohapatra, 2013).

Professional organizations and accreditation agencies provide different levels and details of descriptions regarding what skills and knowledge sets students should possess to assure that they are ready for their professional challenges. In many cases these descriptions just state that curriculum “... includes learning experiences in such general knowledge and skill areas as: ... Use of information technology" (AACSB, 2003).

Fish, Segall, Seydel, \& Sinclaire (2010) provided a detailed overview of what factors might impact students' technology fluency. Their report introduced an assessment method to measure computer skills of business students that can be used to report on the AACSB accreditation goal completion. The authors also recommended a way to evaluate course impact on student skill development (Fish, Segall, Seydel, \& Sinclaire, 2010).

\section{What Do Employers Want?}

There have been several attempts to create a better alignment between employer needs and content offered in the business core information systems courses. Based on a follow-up survey conducted in Fortune 500 companies researchers reported a significant increase in the number of skills that the respondents rated as "recommended" or "strongly recommended" for business students. Beyond the expected generic areas covering hardware, operating systems, productivity software, telecommunication and workgroup software, programming, and information systems skills they also recommended that business professors in specific disciplines should consider integrating enterprise resource planning (ERP) or supply chain management (SCM) software into related courses. They also recommended that business students should consider taking more information technology application courses as electives to be better equipped for the job market (Zhao \& Alexander, 2002). From a career perspective it is important that not only technology is built into education and training but from a workforce development perspective it is equally important that practitioners develop a willingness to accept new technology and embrace continuous changes (Bimrose, Kettunen, \& Goddard, 2014). Research indicates that greater acceptance of technology or technology specialization in organizations has a positive impact on institutional performance (Bharati \& Chaudhury, 2012).

Studies indicate that employers are not totally satisfied with the degree to which students are being prepared for their chosen careers. Cisco Systems has captured the trend of education and communicated the paradigm shift that must occur in order for education to address the needs of the 21st century learner. This shift is described as moving from Education 1.0 to Education 3.0 (Daggett, 2010). Through direct meetings and discussions major employers try to address the disconnect between the skills students/graduates have and the future needs of industry. "Employee readiness for an occupation is an on-going challenge. However, in many cases, broad-based educational opportunities can be expected to provide only a portion of the skill and competencies any specific occupation requires. New career aspirants will typically have only a small set of specific skills required to be successful in an occupation" (Anderson \& Grantz, 2013).

In 2003-14, 14,758 respondents from 87 institutions completed SkyFactor's Benchworks Management Education Exit Assessments. When participants were asked whether business programs enhance students' management and leadership skills, as well as, their ability to use and manage technology, six out of ten respondents reported that business program enhanced their ability to be an effective leader and manager but only about one-half of respondents indicated the business program enhanced their ability to use and manage technology (SkyFactor, 2015). Other research results found that students need a certain level of expertise in identified computer applications, proficiency in Microsoft Office applications, learning/content management systems, Internet browsers, search engines, and e-mail (Thompson, Bellanca, Owens, \& Lorenzo, 2012). ACT reports a gap between skill levels required by 571 profiled jobs (between September 2008 and August 2013) and the Applied Technology skill levels possessed by 18,403 individuals who have taken the WorkKey assessment (between September 2012 and August 2013) (ACT, 2012).

AACSB's BizEd journal published a detailed analysis on how important it is to prepare business curriculum with relevant and up-to-date technology content, and how different business schools try to achieve those goals. "Businesses increasingly want employees who have a T-shaped portfolio skills. The vertical dimension represents deep expertise in a specific area ... The horizontal dimension represents an ability to manage IT interdependencies ... The trouble is, individuals with those skills are in short supply." Only a few schools started to offer courses and develop programs that 
address those needs (Shinn, 2012).

\section{IS/IT Courses in the Business Core}

There are no recent agreements and updated standards on information systems literacy requirements. The previous recommendations were reviewed by the ACRL Standards Committee and approved by the Board of Directors of the Association of College and Research Libraries (ACRL) in 2000. These standards are similar to the guidelines published by the American Association for Higher Education (1999) and the Council of Independent Colleges (2004). The weights and relevance of the listed areas and requirements have shifted since their publication, and with the changes in technology there are several important ones that are missing.

Business schools provide courses in the business core that cover the basics of information systems: concepts of hardware, operating systems, networking, security, foundations of systems development, and teach skills in productivity tools. But there is no general agreement on what needs to be taught, whether it should be only one level (beyond computer literacy), and/or the student's need for more leveraged skills to be better prepared for their jobs and meet the higher levels of business requests.

Standard 15 (2003) and Standard 9 (2013) of the Business Accreditation Standards (AACSB, 2003; AACSB, 2013) discuss curriculum. AACSB does not use a prescriptive approach. Rather they lay out general guidelines such as "Statistical data analysis and management science as they support decision-making processes throughout an organization", "Financial theories, analysis, reporting, and markets" and "Use of information technology". It is up to the programs themselves to decide the number and content of courses.

\section{Methodology}

Our school is making preparations for AACSB accreditation and the authors of this research have asked the question: where are we compared to our peer institutions (the institutions that have been chosen as being similar in mission and used for salary comparison, etc.) in offering information systems topics in the required business core, and how the current offerings match up with constituents' demands. Data was collected from our 61 peer institutions by examining program listings from the institutions' web sites. Eighty-nine per cent of these institutions are AACSB-accredited. Data was collected relating to the structure of the business core in general and the information systems component of that core in particular. Every program did not have a specific list for the business core courses. In such cases the program sheets for multiple majors in the school of business were compared to divine the business core requirements.

\section{Results and Discussion}

One of the challenges for most IS programs is that the business core has limited room for adding more IS courses or content. Faculty would typically consider the business core to be fairly standard across institutions. For example, it would contain an information systems course, one or two accounting courses as well as courses from the management, marketing, and finance departments. One or two statistics courses or one statistics course and a management science course are typically included. Some business cores also have a course relating to business communication. Finally the core would be rounded off by a senior experience course, typically a strategic management course. Therefore adding more IS content immediately meets resistance from the other departments that contribute to the core.

The collected data was examined to determine the structure of a typical business core for the 61 peer institutions.

Table 1. Business core

\begin{tabular}{lll}
\hline Courses & $\mathrm{N}$ & $\%$ \\
\hline Accounting I & 61 & $100 \%$ \\
Marketing & 61 & $100 \%$ \\
Accounting II & 60 & $98 \%$ \\
Finance & 60 & $98 \%$ \\
Management & 60 & $98 \%$ \\
Statistics I & 58 & $95 \%$ \\
Business Law & 58 & $95 \%$ \\
Business Capstone & 58 & $95 \%$ \\
Information Systems I & 52 & $85 \%$ \\
Management Science* & 47 & $77 \%$ \\
Business Communication & 34 & $56 \%$ \\
Computer Applications & 31 & $51 \%$ \\
Statistics II & 18 & $30 \%$ \\
International Business & 15 & $25 \%$ \\
Information Systems II & 2 & $3 \%$ \\
\hline
\end{tabular}

*Includes related titles such as Decision Science, Operations Research, and Production Management.

Table 1 shows the percentage of schools that have the listed courses in their core. 
The first eight courses - occurring in $95 \%$ or more of the programs - are the fundamental component of the business cores in these peer institutions. In addition $85 \%$ of schools have an information systems course and $77 \%$ have a management science course. These 10 courses are what we would consider the dominant ones in business cores.

Only $56 \%$ of programs have a business communications course. $30 \%$ have a second statistics course. In terms of statistical analysis and management science, the range varies from as little as just one statistics course to two statistics and a management science course. Some courses, such as "Diversity in Workplace" and "Supply Chain Management" featured less frequently than those in Table 1.

Note too, that although a program may not have a particular course specified, for example management science, the topics may still be covered across the curriculum.

\subsection{Capstone in the Business Core}

Table 2. Business core capstone courses

\begin{tabular}{ll}
\hline Course Name & N \\
\hline Strategic Management & 24 \\
Business Policy & 6 \\
Business Policy and Strategy & 5 \\
Administrative Policy & 4 \\
Business Strategy & 3 \\
Strategic Management and Business Policy & 3 \\
Cases \& Concepts in Business Policy & 1 \\
Competitive Strategy & 1 \\
Corporate and Business Strategy & 1 \\
Integrated Business Strategy & 1 \\
Integrating Experience & 1 \\
Integrative Business Strategy & 1 \\
Management & 1 \\
Management Strategy & 1 \\
Managing Policy \& Strategy & 1 \\
Senior Capstone & 1 \\
Small Business Analysis \& Strategy or Strategy \& Policy & 1 \\
Strategic Analysis & 1 \\
Strategy \& Policy & 1 \\
None / choice of several & 3 \\
\hline
\end{tabular}

Most programs (95\%) require a Business capstone course. Table 2 shows the varied names for this course. The predominant name of the course is Strategic Management. Only three of the peer institutions did not require such a course.

\subsection{Information Systems and the Business Core}

The information systems components across the 61 peer institutions are tabulated in Table 3.

Table 3. Information Systems Courses

\begin{tabular}{lll}
\hline IS-Related Content & $\mathrm{N}$ & $\%$ \\
\hline One IS course only & 27 & $44 \%$ \\
Applications + one IS course & 23 & $38 \%$ \\
Applications only & 6 & $10 \%$ \\
No computer-related course & 3 & $5 \%$ \\
Applications + two IS courses & 2 & $3 \%$ \\
\hline
\end{tabular}

Only five per cent of programs did not have any computer technology course listed in the Business core. Even this small percentage is surprising given the ubiquitous nature of computing in the business world. Thirty-eight per cent have the combination that many would expect, i.e. a computer applications course and one information systems course. This is a typical combination as the applications course is usually the prerequisite for the information systems. The faculty teaching the information systems course can assume students have basic knowledge in Excel and Access so they can focus on solving business problems with these tools. Only three per cent of schools required an applications course and two information systems courses. Table 3 indicates that $10 \%$ of programs have only an applications course listed in their curriculum. This is surprising given the importance of information systems concepts in the business field such as using information systems for a competitive edge, enterprise resource planning systems, etc.

\section{Summary, Conclusions, and Further Research}

Results show that $85 \%$ of the 61 peer institutions had one IS course and only three percent had two IS courses. Thirty-eight percent of business programs had an applications course in addition to an IS course. Surprisingly in today's information-intensive business world, five percent of programs had no computer course of any kind. 
IS content in the business core is often restricted due to the varied set of other coursework business students should be exposed to and the politics of departments protecting their "turf". IS departments may have to do with one IS course in the core and therefore departments must carefully manage the content of the IS course. Further research in this area could be done to look at the detailed course syllabi of all the Information Systems courses offered at various institutions. This would allow for a better understanding of what is being taught and at what level. This could be compared with the needs of industry and to make recommendations about changes to the content of IS in the Business core.

\section{References}

AACSB (2003). Business Accreditation Standards, Standard 15: Management of Curricula. Retrieved from http://www.aacsb.edu/ /media/AACSB/Docs/Accreditation/Standards/2003\%20Standards/2012-business-accredita tion-standards-update.ashx

AACSB (2013). Business Accreditation Standards, Standard 9: Curriculum Content. Retrieved from http://www.aacsb.edu/ /media/AACSB/Docs/Accreditation/Standards/2013-bus-standards-update-jan2015.ashx

ACT (2012). Applied Technology Job Skill Comparison Chart. Retrieved from http://www.act.org/workkeys/charts/tech.html

Allen, I. E., \& Seaman, J. (2011). Going the Distance: Online Education in the United States, 2011. Retrieved from http://www.onlinelearningsurvey.com/reports/goingthedistance.pdf

Anderson, C., \& Grantz, J. F. (2013). Skills Requirements For Tomorrow's Best Jobs - Helping Educators Provide Students with Skills and Tools They Need. Retrieved from https://news.microsoft.com/download/presskits/education/docs/idc_101513.pdf

Barry, J. J. (2012). Governance Matters: The Impact of Information Communication Technology on the Poor in Mexico. In APSA 2012 Annual Meeting Paper. Retrieved from http://ssrn.com/abstract=2110202

Bharati, P., \& Chaudhury, A. (2012). Technology Assimilation across the Value Chain: An Empirical Study of Small and Medium-Sized Enterprises. Information Resources Management Journal, 25(1), 38-60, January-March. https://doi.org/10.4018/irmj.2012010103

Bimrose, J., Kettunen, J., \& Goddard, T. (2014). ICT - the new frontier? Pushing the boundaries of careers practice. British Journal of Guidance \& Counselling, 43(1), 8-23. https://doi.org/10.1080/03069885.2014.975677

Boh Podgornik, B., Dolničar, D., Šorgo, A., \& Bartol, T. (2015). Development, testing, and validation of an information literacy test (ILT) for higher education. Journal of the Association For Information Science And Technology, https://doi.org/10.1002/asi.23586

Daggett, W. (2010). Preparing Students for Their Technological Future. White paper, International Center for Leadership in Education. Retrieved from http://www.leadered.com/pdf/Preparing\%20Students\%20for\%20Tech\%20Future\%20white\%20paper.pdf

Davies, A., Fidler, D., \& Gorbis, M. (2011). Future Work Skills 2020. Retrieved from http://www.iftf.org/uploads/media/SR-1382A_UPRI_future_work_skills_sm.pdf

Evangelista, R., \& Vezzani, A. (2012). The impact of technological and organizational innovations on employment in European firms. Industrial and Corporate Change, 21(4), 871-899. https://doi.org/10.1093/icc/dtr069

Fish, K., Segall, R., Seydel, J., \& Sinclaire, J. (2010). Assessing Technology Skills of Business Students. Retrieved from http://www.researchgate.net/publication/265632153_Assessing_Technology_Skills_of_Business_Students

Grant, D. M., Malloy, A. D., \& Murphy, M. C. (2009). A Comparison of Student Perceptions of their Computer Skills to their Actual Abilities. Journal of Information Technology Education, 8(1), 141-159.

Groux, C. (2012). Education Professionals Say Students Need More Technology Skills. US News University Directory, January 16, 2012. Retrieved from http://www.usnewsuniversitydirectory.com/articles/ education-professionals-say-students-need-more-tec_12073.aspx\#.UOjN9KXBz5h

Gruzd, A., \& Haythornthwaite, C. (2011). Networking Online: Cybercommunities. In: The SAGE Handbook of Social Network Analysis, 167-179, SAGE, London.

Hamilton, D. (2010). The Online Student's User Manual: Everything You Need to Know to be a Successful Online College Student. Amazon Digital Services, Inc., ASIN: B00413QFP6

Hargittai, E. (2007). The Social, Political, Economic, and Cultural Dimensions of Search Engines: An Introduction. Journal of Computer-Mediated Communication, 12(3), 769-777. https://doi.org/10.1111/j.1083-6101.2007.00349.x

Haythornthwaite, C. (2001). The Internet in everyday life. American Behavioral Scientist, 45(3), $363-382$. https://doi.org/10.1177/00027640121957240 
Henno, J., Jaakkola, H., \& Makela, J. (2012). Quo vadis, IT education? MIPRO 2012, Proceedings of the 35th International Convention (pp. 1232-1238), Opatija, Croatia.

MacKay, K., \& Vogt, C. (2012). Information Technology in Everyday and Vacation Contexts. Annals of Tourism Research, 39(3), 1380-1401. https://doi.org/10.1016/j.annals.2012.02.001

Manochehri, N., Al-Esmail, R., \& Ashrafi, R. (2012). Examining the Impact of Information and Communication Technologies (ICT) on Enterprise Practices: A Preliminary Perspective from Qatar. The Electronic Journal of Information Systems in Developing Countries, 51(3), 1-16.

Massimi, M., Dimond, J. P., \& Le Dantec, C. A. (2012). Finding a New Normal: The Role of Technology in Life Disruptions. Proceedings of the ACM 2012 Conference on Computer Supported Cooperative Work, (pp. 719-728), ACM New York, NY, USA. https://doi.org/10.1145/2145204.2145314

Mohapatra, S. (2013). Business school education and technology - a case study. Education and Information Technologies, 20, 335-346. https://doi.org/10.1007/s10639-013-9287-3

Raghavan, S. (2006). Blogs and Business Conversations. Journal of Creative Communications, 1(3), 285-295. https://doi.org/10.1177/097325860600100305

Raphaeli, O., Naveh, G., Levi, M., Berman, S., \& Fink, L. (2012). Measuring The Business Value of E-Business Technologies. Proceedings of the Information Systems (ILAIS) Conference (pp. 101-104), Haifa, Israel.

Rob, M A., \& Etnyre, V. (2015). Student Perceptions in Teaching Principles of Management Information Systems, Journal of Education for Business. https://doi.org/10.1080/08832323.2015.1074151

Schuetze, C. F. (2012). Europe Trying to Catch Up in Teaching e-Business. The New York Times. Retrieved from http://www.nytimes.com/2012/10/25/world/europe/europe-trying-to-catch-up-in-teaching-e-business.html?_r=0

Shah, M. M., Hassan, R., \& Embi, R. (2012). Technology acceptance and computer anxiety. Proceedings of the 2012 International Conference on Innovation Management and Technology Research (ICIMTR) (pp. 306-309), Malacca, Malaysia. https://doi.org/10.1109/ICIMTR.2012.6236408

Shaofu, S. (2012). Education of Business Managers in the Background of Internalization. Proceedings of the 2012 Second International Conference on Business Computing and Global Informatization (BCGIN-IEEE) (pp. 350-353), Sanghai, China. https://doi.org/10.1109/BCGIN.2012.97

Shinn, S. (2012). The Intersection of Business \& Technology. BizEd, November/December, 18-23.

SkyFactor (2015). How Do Undergraduate Business Programs Contribute To Students' Skills? Benchworks Undergraduate Business Assessment Research Note. Retrieved from

http://www.skyfactor.com/wp-content/uploads/2015/03/How-do-undergraduate-business-programs-contribute-to-st udents-skills.pdf

Thompson, J., Bellanca, M., Owens, N., \& Lorenzo, G. (2012). Essential Computer Skills for College Students. International Journal of Information Systems in the Service Sector, 4(1), 53-66. https://doi.org/10.4018/jisss.2012010104

Thorell, M., Fridorff-Jens, P K., Lassen, P., Lange, T., \& Kayser, L. (2015). Transforming students into digital academics: a challenge at both the individual and the institutional level. BMC Medical Education, 15, 48. https://doi.org/10.1186/s12909-015-0330-5

Verhoeven, J. C., Heerwegh, D., \& De Wit, K. (2012). First year university students' self-perception of ICT skills: Do learning styles matter? Education and Information Technologies, 17(1), 109-133. https://doi.org/10.1007/s10639-010-9149-1

Wallace, P., \& Clariana, R. (2005). Perceptions vs. Reality: Determining Business Students' Computer Literacy Skills and Need for Instruction in Information Concepts and Technology. Journal of Information Technology Education, $4,141-151$.

Young, J. R. (2012). A Conversation With Bill Gates About the Future of Higher Education. The Chronicle of Higher Education, June 25, 2012. Retrieved from http://chronicle.com/article/A-Conversation-With-Bill-Gates/132591/

Zhao, J. J., \& Alexander, M. W. (2002). Information Technology Skills Recommended for Business Students by Fortune 500 Executives. Delta Pi Epsilon Journal, 44(3), 175-189.

\section{Copyrights}

Copyright for this article is retained by the author(s), with first publication rights granted to the journal.

This is an open-access article distributed under the terms and conditions of the Creative Commons Attribution license which permits unrestricted use, distribution, and reproduction in any medium, provided the original work is properly cited. 